\title{
Redirecting the Wheels of Natural Progression: Review of Synthetic Biology and the African Biotechnology Revolution
}

\author{
Garang B. N.., Onkware A. O. \\ Department of Biological Sciences, University of Eldoret, Kenya
}

Copyright $(2016$ by authors, all rights reserved. Authors agree that this article remains permanently open access under the terms of the Creative Commons Attribution License 4.0 International License

\begin{abstract}
Synthetic biology is broadly understood as the deliberate design of novel biological systems and organisms that draws on principles elucidated by biologists, chemists, physicists and engineers, in essence it is about redesigning life'. The main aim of this work was to review the state of synthetic biology in Africa in contrast with the trends of both conventional and modern biotechnologies and to give highlights on the future novelty of synthetic biology. The study showed that synthetic biology in Africa has not yet fully come of age, and that plant biotechnology has been extensively adopted in the continent. The potentials which can be achieved with this technology are unimaginable and can bring about great progress in developing nations. However greater political initiatives and government policies needs to be instigated if the advantages of this technology are to be fully felt in Africa, this thus calls for further research and investments into the technology.
\end{abstract}

Keywords Synthetic Biology, Modern Biotechnology, Plant Biotechnology, Exploitation of Natural Systems and Design of Organisms

\section{Introduction}

\subsection{Problem Statement}

Basic agriculture is central to the economy of most African countries; development of profitable pharmaceutical And other large industrial sector's has been underdeveloped, the understanding, application and use of synthetic biology can positively reverse this situation and make Africa compete technologically with developed nations.

\subsection{Justification}

While many countries have recognized the importance of setting synthetic biology priorities and consolidating resources in a few research institutions that have the potential to grow quickly into centers of excellence in biotechnology, Many African countries have not established and applied strategies for identifying and promoting the use and conservation of biodiversity by adopting synthetic biology as a modern scientific tool, it was the purpose of this paper to review the extent to which this technology is already applied in the continent and the potential benefits it might have on the future and progress of the continent.

\subsection{Objectives}

\subsubsection{Main Objective}

To review the novelty and potential industrial applications of synthetic biology in Africa.

\subsubsection{Alternative Objectives}

- To review the state of synthetic biology in Africa,

- To review the various political and social hindrances stopping the effective application of synthetic biology in solving the developmental agendas in African countries.

\subsection{Background Information}

\subsubsection{Synthetic Biology}

Synthetic biology is the design and construction of biological devices and systems for useful purposes. [29]. Synthetic biology combines a number of scientific disciplines and is generally understood to involve the deliberate design of biological systems, using standardized components that have been created in a laboratory [10], it encompasses a variety of different approaches, methodologies, and disciplines with a focus on engineering biology and biotechnology. [9], Using genetically modified living organisms or their products for commercial purposes is an emerging area in biotechnology. [22]. 
The behavior of all living matter is governed by gene expression, the process by which biological materials such as proteins are made. So synthetic biology's "parts" are the DNA sequences that contain certain manufacturing instructions. When these parts are stuck together, the genes are expressed and the required protein is made. [14]. Synthetic biologists thus design and construct complex artificial biological systems [2]. The goal of synthetic biology is to extend or modify the behavior of organisms and engineer them to perform new tasks. [2].

Synthetic biology has been hailed as the key to a new post-oil global economy of abundance for all and has been backed up by high profile research into the creation of synthetic artemisinin, a vital anti-malarial drug [10] critics however argue that the oil and military defense industries see synthetic biology as the perfect vehicle for the continuation of their power and accumulation under the guise of fighting climate change. [10]

\subsubsection{History}

Although the current metamorphosis of synthetic biology as an independent discipline is fairly resent, its origin and development has a history spanning the twentieth century and is very much tied to the developments of techniques in biotechnology, genetic engineering and microbial gene manipulations.

However, the first use of the word synthetic biology was in Stéphane Leducs's publication (Théorie physico-chimique de la vie et générations spontanées) in 1910 and (LaBiologieSynthétique) in (1912) and in 1974, the Polish geneticist Wacław Szybalski used the term "synthetic biology", [31].

The applications of this technology in developed countries has already started as witnessed in May 2010, when Craig Venter, the doyen of the genomics world, claimed that his company had created the world's first self-reproducing organism [27].

In realizations of the benefits this new field promises Africa has also joined the race to adopt the technology, and countries such as South Africa have made collaborations with multinational companies to promote this new technology. Undoubtedly, Synthetic Biology's own poster project has been the joint research carried out at UCB to create synthetic artemisinin, a key anti-malarial drug the research began in 2004 and is a joint effort of UCB, the Institute for One World Health (iOWH) and Amyris Inc a private genomics company [10].

\subsubsection{The Methods and Techniques of Synthetic Biology}

'Synthetic biology techniques focus on the engineering of biology and the synthesis of complex, biologically based (or inspired) systems, which display functions that do not exist in nature. This engineering perspective may be applied at all levels of the hierarchy of biological structures, from individual molecules to whole cells, tissues and organisms. [21].

To create a truly synthetic cell or organism a multitude of procedures has to be applied that relies on the following key enabling technologies:

1. SYNTHESIS: here the desired amino acid base pairs needed to produce a specific gene sequence are arranged and chained together to obtain the gene sequences of choice, [24]

2. DNA SEQUENCING: here the desired DNA sequences which will code for the desired proteins are identified sequencing also aids in determining the order of the nucleotide bases in a molecule of DNA, large-scale genome sequencing efforts continue to provide a wealth of information on naturally occurring organisms which provides a rich substrate from which synthetic biologists can construct parts and devices, verifying that they fabricated their engineered system as intended, lastly fast, cheap and reliable sequencing can also facilitate rapid detection and identification of synthetic systems and organism [24].

3. AMPLIFICATION: here the genetic material produced from steps one and two above are multiplied or produced in large quantities by either applying cloning techniques in biotechnology or by doing PCR reactions.

4. MODELING: here a specific system or unit of the actual target organism or unit is reproduced Models inform the design of engineered biological systems by allowing synthetic biologists to better predict system behavior prior to fabrication. Synthetic biology benefit from better models of how biological molecules bind substrates and catalyzes reactions, how DNA encodes the information needed to specify the cell and how multi-component integrated systems behave [16].

5. RECONSTRUCTION: here the final assembled genetic material is then inserted into an empty/non DNA containing cell (nucleus) cell growth conditions are then optimized in vivo and the desired cell lines are produced using the techniques of biotechnology [24]

6. MEASUREMENT: this is the final step after the synthetic cell or system has been produced evaluator mechanisms are then employed to test the functionality of the system or the authenticity that a new cell has been produced; these are usually Precise and accurate quantitative measurements of biological systems crucial in improving understanding of the biology of the "synthetate". Such measurements often help to elucidate how biological systems work and provide the basis for model construction and validation, the differences between predicted and measured system behavior can identify gaps in understanding and explain why synthetic systems don't always behave as intended. Microscopy and flow cytometry are examples of useful measurement technologies. [16].*fig no.1 


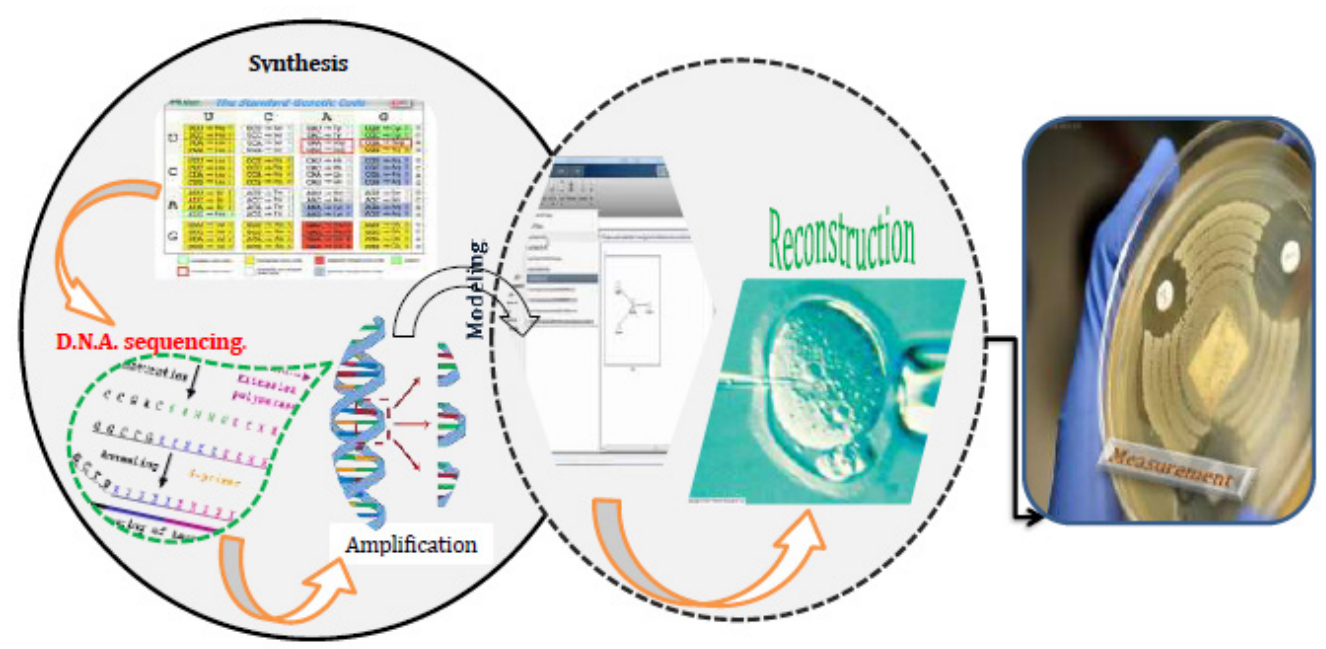

Key:

Step 1= Synthesis.

Step $2=$ D.N.A. sequencing.

Step $3=$ Amplification.

Step $4=$ Modeling.

Step $5=$ Reconstruction

Step $6=$ Measurement.

N.b .In synthetic biology the order of precedence is always maintained unlike in conventional biotechnology where some stages can be merged, this is because unlike in biotechnology and entirely new system is constructed.

Figure 1. Methods and techniques of synthetic biology

\subsubsection{Applications of Synthetic Biology}

The objective of synthetic biology is the design and construction of new biological devices and systems to deliver useful applications. Numerous synthetic gene circuits have been created in the past decade, including bistable switches, oscillators, and logic gates [2], and possible applications abound, ranging from biofuels, to detectors for biochemical and chemical weapons, to disease diagnosis, to gene therapies. [21].

- Although the above mentioned applications and research work carried out in the field of synthetic biology have mainly been witnessed in developed countries Africa on itself has not completely been left far behind.

The potential for the technology in the global fight against Malaria is considerable, as are the potential impacts of synthetic artemisinin on the cultivation of Artemisia in East Africa, where a fledgling industry supporting thousands of small holder farmers is developing. South Africa was initially heavily involved in synthetic artemisinin and there are currently plans for the development of a national synthetic biology strategy in the country, [10].

Encouraging developments include the newly established Stellenbosch Biomass Technology Company, which has teamed up with the Canadian firm Mascoma with a view to producing second generation agro-fuels in South Africa using both techniques of synthetic biology and genetic engineering. [10].

As mentioned above, the majority of the work performed in Synthetic Biology has been more in what we will call Basic Science than in Applied Science[16], Large scale social applications of synthetic biology have not really been achieved this is because Private funding for synthetic biology research is directed overwhelmingly towards agro-fuel applications, with big-oil leading the way. In 2009, Exxon Mobil, in its first major investment in agro-fuels, entered into a $\$ 600$ million partnership with Synthetic Genomics to develop transportation fuels from algae [10] However, this could change rapidly. ${ }^{* \text { fig.no. } 2}$ 


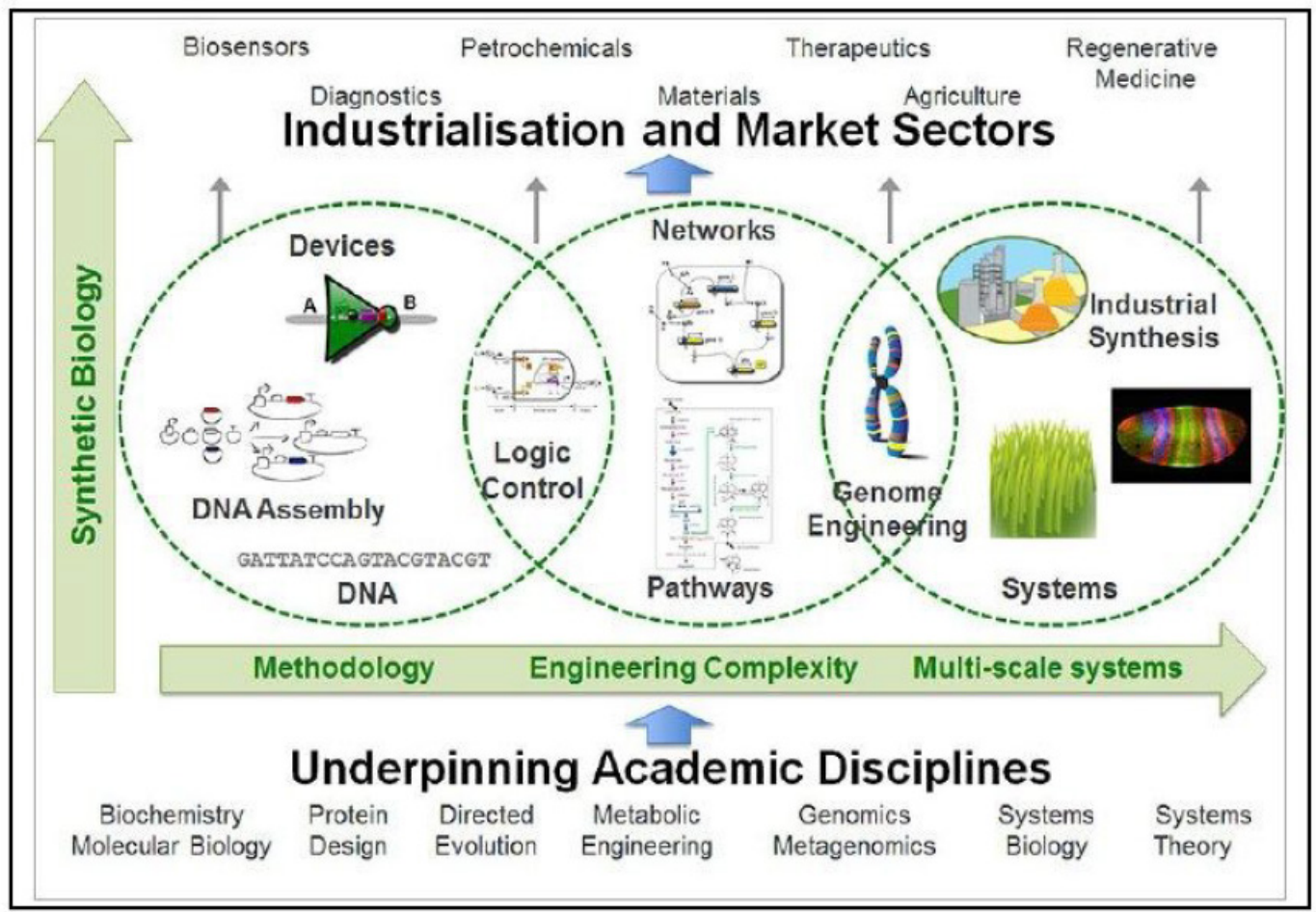

Figure 2. Applications of synthetic biology in various fields, (Image reprinted from, Google images/www.asiabiotech.com18/1805/18050039x.html/)

\subsubsection{Social and Ethical Challenges of Synthetic Biology}

One of the major concerns about synthetic biology is whether there will be real benefits for the society down the line or are biologists just trying to play God by tampering with Mother Nature[32],with all these uncertainties on the importance of synthetic biology, over 100 environmental and civil society groups, including Friends of the Earth, the International Center for Technology Assessment and the ETC Group issued the statement The Principles for the Oversight of Synthetic Biology, On March 13, 2012 which call for a worldwide moratorium on the release and commercial use of synthetic organisms until more robust regulations and rigorous biosafety measures are established[4].

In addition to numerous scientific and technical challenges, synthetic biology raises questions for ethics, biosecurity, biosafety,[29] To date, key stakeholders (especially in the US) have focused primarily on the biosecurity issues, especially the so-called dual-use challenge, which recognize that while the study of synthetic biology may lead to more efficient ways to produce medical treatments, it may also lead to synthesis or redesign of harmful pathogens (e.g., smallpox) by malicious actors[17].

The major technical misunderstanding about synthetic biology is the assumption that In an ideal world, Synthetic Biology should be able to rely on a list of standardized parts (amino acids, bases, proteins, genes, circuits, cells, etc.) that would successfully be joined together to create a new biological function, However, life is not that simple, with all the daunting complexity of living systems, especially eukaryotes. [21].

\section{Trends in Synthetic Biology}

\subsection{Synthetic Biology/Genetic Engineering at the Global Stage}

Studies have shown that developed nation's modern Genetic engineering had significantly, revitalized the application of the scientific knowledge generated in university departments in the USA, Japan and Europe in the 1970 s by the production of many industrially applicable products [25], It has revolutionized the way humanity perceives of and uses living matter [26], Globally Research and development in the area of genetic engineering are now a source of new products that are improving agricultural production, human and animal health, the environment, and industry in general [22].

\subsection{Factors in Favor of Synthetic Biology in Developed Countries and Newly Industrialized States}

Synthetic biology and Genetic engineering activities have been made possible and are supported in developed nations by the establishment of various authorities and regulatory bodies [14].

Research carried out by the Synthetic Biology Project has revealed that there are currently over 180 organizations in the United States and a further 50 in Europe that are involved in synthetic biology research, development and commercialization [10]. 


\subsubsection{USA}

The USA is the leader in biotechnology R\&D and its commercialization, nowhere in the world are there major deliberate efforts to commercialize biotechnology stronger than in the USA, this has been achieved because, The USA has organized its biotechnology R\&D systems so as to mobilize and enlarge its commercial capabilities and to shape the character of its competitiveness at the international level [14].

On the public R\&D front, deliberate policy measures were introduced in the late 1980s and early 1990s to stimulate and/or enrich the active involvement of universities in biotechnology. Significant federal funding was allocated to basic research (mainly biomedical) in the universities [3]. Such public research bodies as the National Institutes of Health (NIH), the National Science Foundation (NSF) and the US Department of Agriculture (USDA) have also allocated considerable funding to basic research [20]. In 1987 the US government spent US\$2700 billion supporting biotechnology [14].

\subsubsection{Europe/Western Europe}

In Western Europe the mid-1980s saw the emergence of biotechnology programs to foster national competitiveness in the development and application of the technology. These programs were established and managed in national public agencies responsible for research in agriculture; environment, mining and human health [14] Cross-sectorial committees were formed to ensure that there was coherence and synergy in national biotechnology activities. Austria, Denmark and Italy were among the first countries to form national biotechnology coordinating committees; Germany developed the first organized government strategy for biotechnology R\&D [23]. The institutions have dedicated biotechnology research programs, and some have accumulated considerable technological capabilities in the area [14]. They are major sources of scientific knowledge in various aspects of biotechnology. Switzerland has an impressive record of national engagement in the development and commercialization of biotechnology. It has a strong private sector biotechnology R\&D with concentration in pharmaceuticals [23].Most of the funding for biotechnology comes from private companies. By 1998 private financing of biotechnology R\&D constituted at least $65 \%$ of the total with a large portion of this going to such areas as recombinant Deoxyribonucleic Acid (rDNA) and exploitation of monoclonal antibody technology to develop diagnostic kits [14].

\subsubsection{Asia}

In Japan it is such big and established companies such as Mitsubishi Chemical and Takeda Pharmaceutical. Japanese private investment has largely focused on pharmaceuticals with increasing rDNA related R\&D. In most other countries of Asia biotechnology $R \& D$ is largely conducted by public sector bodies though there is increasing involvement of local and foreign private companies. [1, 14].

In China Most of the R\&D is in the public sector with heavy government involvement. The State of Science and Technology Commission (SSTC) of China is responsible for the country's planning and policy for biotechnology R\&D in the country [1]. There are four programs under the SSTC: the 863 Program, Key Technologies Research and Development Program, and the Torch and Spark programs. The 863 Program was launched in March 1986 with the objective of enhancing China's international competitiveness and capabilities in science and technology general and biotechnology in particular [1, 14]. The 863 Program has focused on genetic engineering for animals and plants for high yields/improving quality, development of vaccines, gene therapies, protein engineering for food industries, and agriculture [14].

In other Asian countries such as Taiwan and Korea overall government spending on R\&D forms a relatively high percentage of gross national product. These countries have targeted pharmaceuticals and agriculture $[1,14]$.

\section{The State of Genetic Engineering in Africa}

The past two decades have witnessed increased investment in biotechnology research and development (R\&D) by a number of African countries. Public research institutions and a few private companies in the region have established projects or programs on biotechnology R\&D. The nature of activities and levels of investment in the technology vary from one country to another and from one sector to another [25].

Experts in the field agree that "If Africa were to join the synthetic biology race and realize its potential, it could not only reduce the continent's dependency on oil-bringing foreign exchange savings and much needed political stability, but also improve food and energy security, support the industrial sector, alleviate poverty in rural areas, boosting local agriculture production, giving farmers access to additional markets and revenues and generating jobs." [10].

Development of biotechnology, mostly plant biotechnology, in African countries relies on established biotechnological centers, either of a regional or international character, that specialize in in vitro cultivation of cash crops such as banana, coffee, cocoa, palm-oil, vanilla; and food crops such as maize, millet, cassava and cowpea [20].

On the whole, African countries are at different stages in the development of biotechnology. Some have moved up the technology ladder and are applying more sophisticated techniques such as molecular markers, but others are still in the tissue culture level of application [14]. Table 1 summarizes selected biotechnology research in Africa, from a study done by: Brink, Woodward and Da Siva, [5] in Juma, 1999b. 
Table 1. Agricultural biotechnology in Africa: some selected cases.

\begin{tabular}{|c|c|}
\hline COUNTRY & AREA OF RESEARCH \\
\hline Egypt & Genetic engineering of potatoes, maize and tomatoes. \\
\hline Morocco & $\begin{array}{l}\text { Micro propagation of forest trees, date palms Development of disease-free and stress tolerant plants, Molecular biology of date palms } \\
\text { and cereals Molecular, markers, field-tests for transgenic tomato. }\end{array}$ \\
\hline Cameroon & $\begin{array}{l}\text { Plant tissue culture of Theobroma cacao (cocoa tree), Hevea brasiliensis (rubber tree), Coffee Arabica (coffee tree), Dioscorea spp } \\
\text { (yam) and Xanthosoma mafaffa (cocoyam) In vitro culture for propagation of banana, oil palm pineapple, cotton and tea. }\end{array}$ \\
\hline $\begin{array}{c}\text { Côte } \\
\text { d'Ivoire }\end{array}$ & $\begin{array}{l}\text { In vitro production of coconut palm (Cocos nucifera) and yam Virus-free micro propagation of eggplant (Solanum spp) Production } \\
\text { of rhizobial-based bio fertilizers. }\end{array}$ \\
\hline Ghana & $\begin{array}{l}\text { Micro propagation of cassava, banana/plantain, yam, pineapple and cocoa Polymerase chain reaction (PCR) facility for virus } \\
\text { diagnostics. }\end{array}$ \\
\hline Nigeria & Micro propagation of cassava, yam and banana, ginger Embryo rescue for yam. \\
\hline Senegal & $\begin{array}{l}\text { Well established MIRCEN program Production of rhizobial and mycorhizal-based bio fertilizers for rural markets Well established } \\
\text { in vitro propagation of tree species in cooperation with several international agencies. }\end{array}$ \\
\hline Ethiopia & Tissue culture research applied to Micro propagation of forest trees. \\
\hline Kenya & $\begin{array}{l}\text { Production of disease free plants and micro propagation of pyrethrum, bananas, potatoes, } \\
\text { strawberries,sweetpotato,citrus,sugarcane,Micropropagation,of,ornamentals (carnation, alstromeria, gerbera, anthurium, leopard } \\
\text { orchids) and forest trees In vitro selection for salt tolerance in finger millet, Transformation of tobacco, tomato and beans } \\
\text { transformation of sweet potato with proteinase inhibitor gene, transformation of sweet potato with feathery mottle virus coat protein } \\
\text { gene, tissue culture regeneration of papaya In vitro long-term storage of potato and sweet potato, marker assisted selection in maize } \\
\text { for drought tolerance and insect resistance, well-established MIRCEN providing microbial bio fertilizers in the East African region. }\end{array}$ \\
\hline Uganda & $\begin{array}{l}\text { Micro propagation of banana, coffee, cassava, citrus, granadilla, pineapple, sweet potato In vitro screening for disease resistance in } \\
\text { banana ,Production of disease free plants of potato, sweet potato and banana. }\end{array}$ \\
\hline $\begin{array}{l}\text { South } \\
\text { Africa }\end{array}$ & $\begin{array}{l}\text { Genetic engineering of cereals: maize, wheat, barley, sorghum, millet, soybean, lupins, sunflowers, sugarcane; vegetables and } \\
\text { ornamentals: potato, tomato, cucurbits, ornamental bulbs, cassava and sweet potato; fruits: apricot, strawberry, peach, apple, table } \\
\text { grapes, banana Molecular marker applications of: diagnostic for pathogen detection; cultivar identification. Potatoes, sweet potato, } \\
\text { ornamentals, cereals, cassava; seed-lot purity testing. Cereals; marker assisted selection in maize, tomato; markers for disease } \\
\text { resistance in wheat, forestry crops Tissue culture for: production of disease free plants, potato, sweet potato, cassava, dry beans, } \\
\text { banana, ornamental bulbs; micropropagation of potato, ornamental bulbs, rose rootstocks, chrysanthemum, strawberry, apple } \\
\text { rootstocks, endangered species, coffee, banana, avocado, blueberry, date palm; embryo rescue of table grapes, sunflower and dry } \\
\text { beans; in vitro selection for disease resistance tomato nematodes, guava wilting disease; long term storage. Potato, sweet potato, } \\
\text { cassava, ornamental bulbs; in vitro gene bank collections. Potato, sweet potato, cassava, ornamentals; forest trees, medicinal plants, } \\
\text { indigenous ornamental plants. }\end{array}$ \\
\hline Zimbabwe & $\begin{array}{l}\text { Genetic engineering of maize, sorghum and tobacco, micro propagation of potato, cassava, tobacco, sweet potato, ornamental plants, } \\
\text { coffee Marker assisted selection. }\end{array}$ \\
\hline Zambia & Micro propagation of cassava, potato, trees (Uapaca), banana Hosts SADC Nordic-funded gene bank of plant genetic resources. \\
\hline
\end{tabular}

\subsection{Factors Affecting the Development of Biotech Research in Africa}

There are a number of policy challenges that hinder the development and application of biotechnology in many countries of Africa. First is the lack of clear priorities and investment strategies, as most African countries have not identified specific areas or technological trajectories in which to invest to meet specific goals [14]. Biotechnology policies need to be based on or informed by clearly articulated national priorities and goals, indeed many African countries tend to spread thinly their limited financial and human resources across biotechnology sectors and research agencies [15].

The second set of policy issues pertains to the short-term and low level financing of biotechnology R\&D in many African countries, in most countries of Africa government funding to biotechnology is less than US $\$ 250,000$ per year, the exceptions being Egypt, Mauritius and South Africa, the main challenge for public biotechnology R\&D in Africa is how to find investment capital to sustain basic research and to bring laboratory findings to commercial use [8].

The third category of policy issues, relates to the role of intellectual property protection and its impact on the acquisition, development and diffusion of biotechnology. In most African countries institutions for administering industrial property rights (particularly patents) are still in their infancy [25],this lack of protection of intellectual property rights hampers the development of new technologies, profitable inventions and investments, and initiatives by entrepreneurial biotechnologists. Governments are not taking enough proactive political roles in promoting and protecting biotechnology [30].

Last but not least, in most developing African countries There is the chronic lack of critical, basic infrastructure and facilities, unreliable access to modern communication systems, unreliable power supply and poor availability of chemicals and consumables for research, [5]. Public acceptance is being frustrated by anti-modern biotechnology activism fuelled by internal and external pressure groups [19]. 


\subsection{Future Prospects of Synthetic Biology in Africa}

Research in biotechnology in Africa suggest that Investments in, and development of biotechnological research capacity in Africa would best be accomplished in phases [18]. The first phase is conventional biotechnologies such as plant tissue culture and breeding, which is appropriate for Africa as many of the important food crops such as cassava, sweet potato, yam and banana are vegetatively propagated and could be crossbred to improve quality [13]. The second phase would be the application of biotechnological tools, which can improve the efficiency of selection of varieties/cultivars, the techniques that include anther culture and embryo rescue, as well as molecular marker applications (diagnostics, fingerprinting and marker-assisted breeding) [13]. The third phase is the development of capacity to produce transgenic plants/animals, which would include gene isolation and cloning; gene insertion/transformation; regeneration of transgenic plants/animals followed by commercial release of GMO products [18].

Although much research in genetic engineering in Africa has been focusing on the improvement of agricultural practices, policies aimed at increasing agricultural growth need to give close attention to the impact on environmental and economic sustainability, it is recognized that use of new technologies forms an indispensable part of the potential solution for overcoming the challenges facing Africa [10]. Thus, agricultural technologies including biotechnology tools can help provide better harvests to improve household nutrition and well-being, reduce households' susceptibility to risks of pests and diseases, and climate change, and, provide additional cash income [10]. They can also contribute to a diversifying rural economy, contribute to overall economic growth and address problems of environmental degradation [13].

Many African countries will surely benefit from the above strategy of progression in this technology, it is however necessary to recognize the efforts of some African countries that have already scaled the ladder and made direct attempts to jump from agricultural biotechnology, and embrace the more complex synthetic biology path e.g.

\subsubsection{Synthetic Biology Technological Achievements in Africa}

In South Africa the Department of Science and Technology (DST) has been involved in the field of synthetic biology since 2005, and South Africa intends to achieve international recognition in synthetic biology [7]. The Council for Scientific and Industrial Research (CSIR) 'joined the ranks of pioneers' by establishing a synthetic biology research capacity, a move that would hopefully position South Africa as a 'world leader' in the field. The main focus areas at the CSIR are energy transduction, molecular biomaterials, gene expression and biophysics [10].

As a response to this ambitious government project in supporting synthetic biology in South Africa, Biopad, a biotechnology investment company, joined the private South African genomics company Inqaba and as part of an infrastructure investment by Biopad in 2007, Inqaba purchased genome sequencing equipment from pharmaceutical giant Roche, with the intention of offering sequencing services to customers in Africa. [13].

On 5 July 2010, Stellenbosch Biomass Technologies (SBMT), announced that it had acquired exclusive rights to adapt and commercialize the latest cellulose conversion technology developed by US company, Mascoma Corporation, for the production of biofuels And aims to establish a commercial bioethanol production plant, producing 40-million liters of ethanol by 2014,[10].

Critically looking at the popularity of these few bold attempts to apply synthetic biology in South Africa, it is clear to see that the benefits offered by this technology in achieving the developmental agendas of the continent are of urgent concern, the future adoption and the application of synthetic biology in Africa looks very bright.

\subsubsection{Discussion}

This review clearly shows that the level of awareness and adoption of the techniques of genetic engineering in some African countries is at an advanced level however, Agricultural biotechnology seems to take the lead while biotechnologies related to health, industries and environment are lagging behind, this is mainly because the countries are trying to apply the technology to solve the immediate social and human burdens such as lack of food for their ever increasing populations, synthetic biology on the other hand is very much still in its infancy.

This review has clearly shown that, Africa as a continent will benefit by adapting biotechnology to resolve most of its current problems, according to Mugabe Governments have a fundamental role to play in the promotion of biotechnology, its safe development and its application but seem not to be doing enough at that. The main issues identified here are the fact that national economies are weak and the private sector's abilities to promote technological innovation are constrained by the fragmented nature of the markets [25]. Many African countries face problems of scarce resources for allocation to technological activities in general and biotechnology R\&D in particular. This makes it crucial to institute strategic policies for mobilizing financial resources and enlarging private engagement in biotechnology $R \& D$ [13].

It is also worth noting that South Africa and Egypt are biotechnology leaders in the region. With considerable scientific infrastructure and clear programs on biotechnology, the two countries have focused on cutting-edge biotechnology areas and have commercialized some of their products [14]; however synthetic biology has not yet received as much success as biotechnology.

In east Africa, Kenya leads the region with its biotechnology policy framework in place and more on-going biotechnology related activities, followed by Uganda. 
Tanzania has already developed its biotechnology policy but is slower to translate it into practice especially on matters related to modern biotechnology [13].

In Africa as a whole Biotechnology R\&D are largely undertaken by departments at universities and national agricultural research bodies [25]. This review has clearly shown that the best way forward for Africa as a continent with regards to the maximization of the applications of the developments and gains achieved in the field of synthetic biology will be to adopt More vigorous practical actions in order for synthetic biology to benefit the people of this region in terms of food security, economic growth, improved health and environmental protection [10].

\section{Conclusions}

This review had shown that synthetic biology if exploited in a scientifically ethical manner can improve food and energy security, alleviate poverty, revolutionize the industrial sector, reduce greenhouse gases and promote environmental conservation in Africa. The proper adoption and investments in synthetic biology will greatly improve the quality of life for the people of Africa, and enhance development programs across the continent, however more political good will has to be shown, it is worth noting that research findings show, the adoption and acceptance of the technology by the majority of the authorities in Africa has been due to its quick implementation and lack of better alternatives for the problems facing their populations and not because of complete mastery or long term familiarity with this technology.

\section{REFFERENCES}

[1] Acharya, R. and J. Mugabe (1996). Biotechnology in developing countries: Critical issues of technological capability building, Annual Review of Biotechnology.

[2] Andrianantoandro E, Basu S, Karig DK, Weiss R (2006) Synthetic biology: new engineering rules for an emerging discipline. Mol Syst Biol 2: 0028

[3] Avramovic, M. (1996) an Affordable Development? Biotechnology, Economics and the Implications for the Third World. London: Zed Books

[4] Boyle, Alan (March 14, 2012). "What to do about synthetic life?"Msnbc.msn.com. Retrieved 12 august 2013.

[5] Brink JA, Woodward BR, Da Silva E (1998). Plant Biotechnology: A tool for development in Africa. Electronic J. Biotechnol., 1(3): (online).http://www. ejbiotechnology. cl. Cited on 12th August, 2013.

[6] ChanL Y, Kosuri S, Endy D (2005) "Refactoring bacteriophage T7”. Mol Syst Biol doi: 10.1038/msb4100025.

[7] CSIR Annual Report 2008/09. Council for Scientific and
Industrial Research. http://www.csir.co.za/publications/pdfs/ 12345.pdf (Retrieved 13/08/2013).

[8] Falconi, C. (1999). "Agricultural biotechnology research indicators and managerial considerations in four developing countries". In J.I. Cohen, ed. Managing Agricultural Biotechnology Addressing Research Program Needs and Policy Implications. CAB International.

[9] Folliard, Thomas. "What is Synthetic Biology". synbiosoc. Retrieved 1 March 2013.

[10] Gareth Jones and Mariam Mayer; Acb, briefing paper no. 20, Synthetic Biology in Africa: recent developments 2010 .

[11] Godliving, Mtui; Status of biotechnology in Eastern and Central Africa, Biotechnology and Molecular Biology Review Vol. 6(9), pp. 183-198, December 2011.

[12] Heaven, Douglas. 2013. Quality control opens path to synthetic biology's Ikea. New Scientist. 2013-03-27. [http://www.newscientist.com/article/mg21729104.300-quali ty-control-opens-path-to-synthetic-biologys-ikea.html]. (Retrieved 13/08/2013).

[13] Inqaba biotechnologies: http://www.inqababiotec.co.za/inde x.php/about-us (Retrieved 13/08/2013).

[14] John Mugabe; Atps special series no. 3: Biotechnology in Sub-Saharan Africa: Towards a policy research agenda, 2002.

[15] Kasonta, J. (1999). Recent Biotechnology Research and Development in Tanzania. Background Paper prepared for the Regional Workshop on Biotechnology Assessment: Regimes and Experiences, organized by ACTS, September 1999.

[16] Kaznessis Y N (2007). "Models for synthetic biology". BMC Systems Biology 1: 47. doi: 10.1186/1752-0509-1-47. PMC 2194732. PMID 17986347.

[17] Kelle A (2009). "Ensuring the security of synthetic biology - towards a 5P governance strategy" (PDF). Systems and Synthetic Biology 3 (1-4): 85-90. doi: 10.1007/s11693-009-9041-8. PMC 2759433. PMID 19816803.

[18] Lynam J K (1995). Building biotechnology research capacity in African NARS. In: Turning priorities into feasible programs. Proceedings of a Regional Seminar on Planning Priorities and Policies for Agricultural Biotechnology, South Africa, pp. 33-40.

[19] Makinde D, Mumba L, Ambali A (2009). Status of Biotechnology in Africa: Challenges and opportunities. Asian Biotechnol. Rev., 11(3): 1-10.

[20] Massola R (1992). Plant biotechnology in Sub-Saharan African Today. In: Plant Biotechnology for Developing Countries. Sasson, A. and Costarini Eds., V. Publ CTA/FAO, Netherlands.

[21] Molecular Systems Biology, 18 December 2007; doi: 10.1038/msb4100202 3:158: EDITORIAL Synthetic biology: promises and challenges.

[22] Nathan S. Mosier, Michael R. Ladisch (2009). Modern biotechnology: Connecting Innovations in Microbiology and Biochemistry to Engineering Fundamentals: Wiley- john wiley \& sons, Inc., publication.

[23] OECD (1998). Biotechnology and the Changing Role of 
Government. Paris: Organization for Economic Cooperation and Development.

[24] Pollack, Andrew (2007-09-12). "How Do You Like Your Genes? Biofabs Take Orders". The New York Times. ISSN 0362-4331. Retrieved 12 august 2013.

[25] Prof Norah K. Olembo, Dr. Felix M'mboyi, Dr. Bernard Nyende, Kennedy Oyugi, Leah Ambani (2010). Status of Crop Biotechnology in Sub Saharan Africa. The African Biotechnology Stakeholders Forum (ABSF), http:// www.absfafrica.org/publications/pdfs (Retrieved $13 / 08 / 2013$ )

[26] Ray. v. Herrein: introduction to biotechnology an agricultural revolution, 2005.thomsons learning Inc.pp1-30.

[27] Robert Lee Hotz (May 21, 2010). "Scientists Create First Synthetic Cell". The Wall Street Journal. Retrieved 12 august 2013.

[28] Schmidt M, Ganguli-Mitra A, Torgersen H, Kelle A, Deplazes A, Biller-Andorno N (2009). "A priority paper for the societal and ethical aspects of synthetic biology" (PDF). Systems and Synthetic Biology 3 (1-4): 3-7. doi: 10.1007/s11693-009-9034-7. PMC 2759426. PMID 19816794.

[29] [29] Schmidt, Markus (2012). Synthetic Biology: Industrial and Environmental Applications (3rd ed.). Weinheim, Germany: Wiley-Blackwell. pp. 1-67. ISBN 3-527-33183-2.

[30] Sengooba T, Grumet R, Hancock, J; Zawedde, B, Kitandu, L, Karembu, M, Meredia K, Nampala P, James O. Ochanda JO, Quemada H, Rubindamayugi, M (2009). Biosafety education relevant to genetically engineered crops for academic and non-academic stakeholders in East Africa. Electronic J. Biotechnol. 12(1) (Online) http://www.ejbiotechnology.cl. Cited on 12th August, 2013.

[31] Synthetic biology: http/www.wikipedia.com retrieved 12 august 2013.

[32] The Ethics of Synthetic Biology: Reinventing the Wheel? Dispatches from the bio-based economy Retrieved 2013-08-14.

[33] United Nations, committee on bioprocess engineering (1992). Biotechnology and Development: Expanding the Capacity to Produce Food. New York: United Nations. 